\title{
Australian Journal of Crop Science \\ Evaluation of West Indian cherry (Malpighia emarginata) rootstock under saline water irrigation and nitrogen fertilization
}

\author{
Edinete Nunes de Melo ${ }^{1}$, Reginaldo Gomes Nobre ${ }^{1}$, Francisco Wesley Alves Pinheiro ${ }^{2}$, Leandro de Pádua \\ Souza ${ }^{2}$, Geovani Soares de Lima ${ }^{2 *}$, Hans Raj Gheyi ${ }^{3}$, Jutahy Jorge Elias ${ }^{1}$, Wandra Laurentino da Silva ${ }^{1}$ \\ ${ }^{1}$ Federal University of Campina Grande, Academic Unit of Agricultural Science, Pombal, 58.840-000, Paraíba, Brazil \\ ${ }^{2}$ Federal University of Campina Grande, Academic Unit of Agricultural Engineering, Campina Grande, 58.109-970, \\ Paraíba, Brazil \\ ${ }^{3}$ Federal University of Recôncavo of Bahia, Nucleus of Soil and Water Engineering, Cruz das Almas, 44.380-000, \\ Bahia, Brazil
}

*Corresponding author: geovanisoareslima@gmail.com

\begin{abstract}
This study aimed to evaluate the growth and quality of CMF 102 West Indian cherry rootstock subjected to irrigation with different salinity levels and nitrogen $(\mathrm{N})$ doses. The experiment was carried out under protected environment, using a randomized block design in a $5 \times 4$ factorial scheme, with four replicates. Treatments consisted of five levels of electrical conductivity of water $-\mathrm{ECW}$ $\left(0.3\right.$ - Control; $1.3 ; 2.3 ; 3.3$ and $\left.4.3 \mathrm{dS} \mathrm{m}^{-1}\right)$ and four nitrogen doses (70, 100, 130 and $160 \%$ of $\mathrm{N}$ recommendation). CMI $102 \mathrm{West}$ Indian cherry rootstock growth was evaluated through plant height, stem diameter, number of leaves, leaf area, shoot and total dry phytomass and Dickson quality index of seedlings 165 days after emergence. Additionally, the absolute growth rate of plant height was evaluated from 45 to 165 days after emergence. The results indicated that irrigation with ECw up to $2.22 \mathrm{dS} \mathrm{m}^{-1}$ leads to a maximum reduction of $10 \%$ in growth and in the quality of CMF 102 rootstock. Highest growth of CMF 102 West Indian cherry rootstock is obtained with fertilization of $70 \%$ of $\mathrm{N}$. The plants of West Indian cherry irrigated with $4.3 \mathrm{dS} \mathrm{m}^{-1}$ of saline water showed an acceptable Dickson quality index; therefore, seedlings with IQD higher than 0.2 considered as good quality. In general, West Indian cherry plants can be classified as sensitive to irrigation with saline waters higher than $0.3 \mathrm{dSm}^{-1}$. No significant effect was found for the interaction between water salinity and $\mathrm{N}$ doses.
\end{abstract}

Keywords: Malpighia emarginata, water quality, fertilization.

Abbreviations: Days after emergence_DAE; plant height_PH; stem diameter_SD; number of leaves_NL; leaf area_LA; shoot dry phytomass_SDP; total dry phytomass_TDP; Dickson quality index_DQl; absolute growth rate of plant height_AGR $\mathrm{R}_{\mathrm{PH}}$.

Introduction

West Indian cherry (Malpighia emarginata) is a rustic plant. Its cultivation expanded in the semi-arid regions of Northeast Brazil due to the favorable climatic conditions, making the crop important for the Northeastern economy (Almeida et al., 2014). The Brazilian Northeast region has irregular rainfalls associated with high temperatures and evaporation rates, making the use of irrigation for rational exploitation of agriculture essential. However, the available waters normally have salt contents that may compromise crop growth and yield. Thus, it is very important to conduct studies and develop techniques that allow for the efficient use of saline water to meet the different demands and adequate form of water use (Ferreira et al., 2016). According to Oliveira et al. (2015), studies have been conducted to find adequate management and/or techniques that allow the use of lower-quality waters, without compromising crop development and yield. Nitrogen performs an important function in the production of amino acids, proteins, nucleic acids and chlorophylls, which may favor such tolerance (Lima et al., 2014). Additionally, the accumulation of these organic solutes inside the cell may increase plant's capacity for osmotic adjustment, helping and favoring the increase of tolerance to certain levels of water and salt stresses (Alves et al., 2012; Nascimento et al., 2015). According to Lima et al. (2015), when the plant is subjected to irrigation with saline water there is a competition in the absorption of nitrate and chloride. When the nitrate concentration is higher in the root zone, chloride assimilation is inhibited. It reduces the effects of the salts and consequently contributes to better plant development. Some researches with other crops, such as banana (Maia et al., 2003), 'caramboleira' (Leal et al., 2007), guava (Amorim et al., 2015), sunflower (Nobre et al., 2010), the cowpea (Furtado et al., 2014) and castor bean (Lima et al., 2015) have reported the beneficial effects of nitrogen application on the growth and development of the plants. Thus, it is necessary to carry out new studies to provide information on the supplied nitrogen doses to meet the nutritional needs of the cultivar and to mitigate the deleterious effects caused by irrigation with saline water. In this context, this study aimed to evaluate the 
growth and quality of CMF 102 West Indian cherry rootstocks subjected to irrigation with different salinity levels and nitrogen $(\mathrm{N})$ doses.

\section{Results and discussion}

\section{Effect of saline stress and nitrogen doses on growth of the} West Indian cherry

According to the analysis of variance (Table 1), irrigation with saline water had significant effect on plant height, stem diameter and number of leaves at 165 days after emergence (DAE). Nitrogen doses had significant effect only on the number of leaves, at 165 DAE. Additionally, there was no significant effect of the interaction (irrigation water salinity and $\mathrm{N}$ doses) on the studied variables.

Increased water salinity significantly inhibited the height of CMF 102 West Indian cherry rootstocks at 165 DAE. The regression equation showed a linear reduction in $\mathrm{PH}(6.39 \%$ reduction per unit increase of $\mathrm{ECW}$ ). Plants irrigated with $\mathrm{ECW}$ of $4.3 \mathrm{dS} \mathrm{m}^{-1}$ showed reduction of $25.56 \%$ in comparison to those subjected to the lowest salt level $(0.3$ $\mathrm{dS} \mathrm{m}^{-1}$ ). According to Lima et al. (2015), reduction in plant growth under stress conditions induced the closure of leaf stomata and decreased transpiration due to the lower absorption of water and nutrients.

Similarly, as observed for plant height (Fig. 1A), the stem diameter of West Indian cherry rootstocks (Figure 1B) also decreased linearly, when water salinity increased. The reduction of $3.05 \%$ at 165 DAE per unit increase in ECW was observed, i.e., plants subjected to the highest ECW level (4.3 $\mathrm{dS} \mathrm{m}^{-1}$ ) showed reduction of $0.79 \mathrm{~mm}$ compared to the lowest ECW $\left(0.3 \mathrm{dS} \mathrm{m}^{-1}\right)$. Reduction in SD may have occurred due to the specific effects of the ions associated with the osmotic effect, which delays cell expansion and division, affecting plant growth (Souza et al., 2015). Irrigation with saline water negatively affects plant growth because of the osmotic and specific effects of the ions, postponing cell expansion and division, causing negative effects on the photosynthetic rate and damaging physiological and biochemical processes of plants (Gomes et al., 2011; Nunes et al., 2012).

The different levels of salinity caused a quadratic effect on the number of leaves at 165 DAE (Fig. 2A). According to the regression equations, the maximum value of 34 leaves was found in plants subjected to $\mathrm{ECW}$ of $0.9 \mathrm{dS} \mathrm{m}^{-1}$. According to Oliveira et al. (2011), reduction in the number of leaves is associated with anatomic and morphological changes of the plant, which occur to reduce water loss. The accumulation of $\mathrm{NaCl}$ in the irrigation water reduces the absorption of water and nutrients by plants, which is an important factor for the reduction in photosynthetic and metabolic processes, leading to reduction in plant growth (Travassos et al., 2012; Oliveira et al., 2013).

Nitrogen doses caused linear reduction in the NL at 165 DAE (Fig. 2B), indicating $5.53 \%$ for every $30 \%$ increase in $\mathrm{N}$ dose, i.e., $16.60 \%$ in the NL of plants fertilized with $160 \%$ compared with those fertilized with $70 \% \mathrm{~N}$. A possibly explanation is that, the $\mathrm{N}$ in the fertilizer associated with the lowest dose did not meet plant requirement already reported by Souza et al. (2016) in the production of 'Crioula' guava rootstock.
According to the analysis of variance (Table 2), the levels of water salinity had significant effect on the absolute growth rate of plant height in the period from 45 to 165 DAE and on shoot dry phytomass, total dry phytomass and Dickson quality index at 165 DAE. On the other hand, $\mathrm{N}$ doses had significant effect only on Dickson quality index. Regarding the interaction between factors (irrigation water salinity $\times \mathrm{N}$ doses), no significant effect was (Table 2).

The increase in water salinity also significantly reduced $A_{G R_{P H}}$ from 45 to 165 DAE (Fig. 3), which decreased by $8.12 \%$ per unit increase of $E C W$, corresponding to a reduction of $0.116 \mathrm{~cm} \mathrm{~cm}^{-1}$ day $^{-1}$ (32.49\%) compared to the plants irrigated with the lowest salt level $\left(4.3 \mathrm{dS} \mathrm{m}^{-1}\right)$. Sousa et al. (2011) reported that this behavior is due to the reduction in water availability and excessive accumulation of $\mathrm{Na}^{+}$and $\mathrm{Cl}^{-}$in plant tissues, altering physiological processes such as quantum yield and gas exchanges.

For shoot dry phytomass (SDP), a decreasing linear response was observed (Figure 4), with reduction of $6.36 \%$ per unit increase in ECW. Highest SDP (5.3 g/plant) was found in plants subjected to salinity of $0.3 \mathrm{dS} \mathrm{m}^{-1}$. Increment of salts in the irrigation water eventually caused nutritional imbalance and such imbalance may lead to losses in the production of vital photoassimilates, such as sugars, carbohydrates and proteins; thus, compromising growth and phytomass production (Silva et al., 2008; Torres et al., 2014). Total dry phytomass (TDP) also decreased with the increment in the levels of irrigation water salinity (Fig. 5). The best results were found at salinity of $0.3 \mathrm{dS} \mathrm{m}^{-1}$, TDP of $7.77 \mathrm{~g}$ per plant, with reduction of $10.35 \%$ per unit increase in $\mathrm{ECW}$, corresponding to $44.53 \%$ between the highest and lowest salinity levels.

\section{Effect of saline stress and nitrogen doses on Dickson quality index of the West Indian cherry}

Dickson quality index (DQI) showed linear reduction when salinity of irrigation water increased. According to the regression equation, there was a reduction of $8.73 \%$ per unit increase of ECW (Fig. 6A). West Indian cherry rootstocks subjected to irrigation with the highest salinity level (4.3 dS $\mathrm{m}^{-1}$ ) exhibited DQI of 0.31 , with reduction of 0.21 (37.56\%)

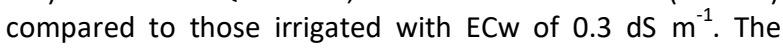
higher the DQI, the better the final quality of the seedling, a fact confirmed in the present study.

According to the regression equation, increasing $\mathrm{N}$ doses significantly influenced the DQI of West Indian cherry rootstocks (Fig. 6B). In other words, for every $30 \%$ increase in $\mathrm{N}$ dose there was a linear increase of $9 \%$ (Fig. $6 \mathrm{~B}$ ), and West Indian cherry rootstocks subjected to fertilization with $160 \% \mathrm{~N}$ showed an increment (15.53\%) equivalent to 0.48 in the DQI. The higher the DQI, the better the quality of the seedling produced, because it relates robustness and biomass distribution balance (Oliveira et al., 2013; Souza et al., 2017).

\section{Materials and methods}

\section{Localization, experimental procedure and treatments}

The study was conducted from March to August 2016 under greenhouse conditions, at the Center of Sciences and AgriFood Technology (CCTA) of the Federal University of Campina 
Table 1. Summary of the analysis of variance for plant height (PH), stem diameter (SD), number of leaves (NL) and leaf area (LA) of CMI 102 West Indian cherry rootstocks under saline water irrigation and nitrogen fertilization at 165 days after emergence - DAE.

\begin{tabular}{|c|c|c|c|c|c|}
\hline \multirow{2}{*}{ Source of variation } & \multirow{2}{*}{ DF } & \multicolumn{4}{|c|}{ Mean squares } \\
\hline & & $\mathrm{PH}$ & SD & NL & LA \\
\hline Saline levels (SL) & 4 & $324.29^{* *}$ & $2.07^{* *}$ & $473.93^{* *}$ & $7232.9^{\text {ns }}$ \\
\hline Linear regression & 1 & $899.65^{* *}$ & $6.41^{* *}$ & $1357.2^{* *}$ & $3737.8^{\text {ns }}$ \\
\hline Quadratic regression & 1 & 94.38 & $0.09^{\text {ns }}$ & $236.16^{*}$ & $20688.7^{*}$ \\
\hline $\mathrm{N}$ doses (ND) & 3 & $52.13^{\mathrm{ns}}$ & $0.06^{\mathrm{ns}}$ & $160.07^{*}$ & $9763.1^{\mathrm{ns}}$ \\
\hline Linear regression & 1 & $142.92^{*}$ & $0.06^{\mathrm{ns}}$ & $472.06^{* *}$ & $7917.2^{\mathrm{ns}}$ \\
\hline Quadratic regression & 1 & $1.12^{\mathrm{ns}}$ & $0.03^{\mathrm{ns}}$ & $2.11^{\mathrm{ns}}$ & $812.4^{\mathrm{ns}}$ \\
\hline Interaction (SL x ND) & 12 & $34.95^{\mathrm{ns}}$ & $0.67^{\mathrm{ns}}$ & $65.03^{\mathrm{ns}}$ & $6645.2^{\text {ns }}$ \\
\hline Blocks & 3 & $826.43^{* *}$ & $5.23^{* *}$ & $1004.3^{* *}$ & $46826.3^{* *}$ \\
\hline CV (\%) & & 14.19 & 11.05 & 25.25 & 17.24 \\
\hline
\end{tabular}

$\mathrm{ns}, * *, *$ respectively not significant, significant at $\mathrm{p}<0.01$ and $\mathrm{p}<0.05$
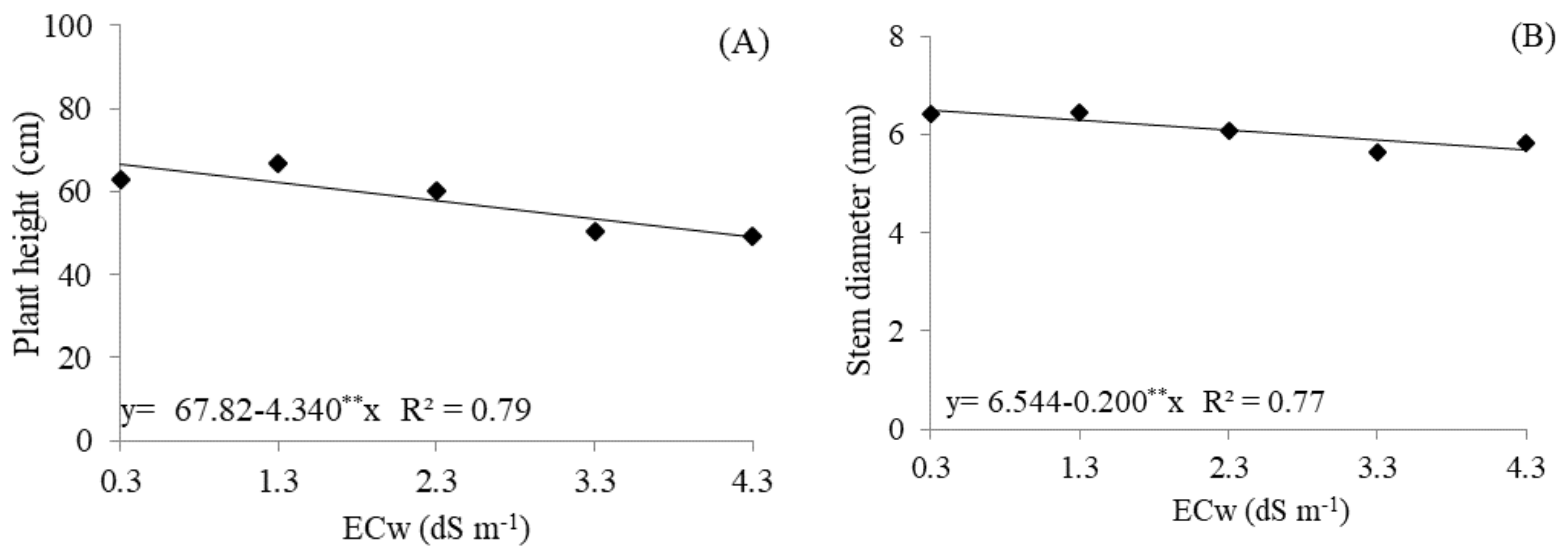

Fig 1. Plant height (A) and stem diameter (B) of a West Indian cherry rootstocks as a function of irrigation water salinity - ECW at 165 days after emergence.
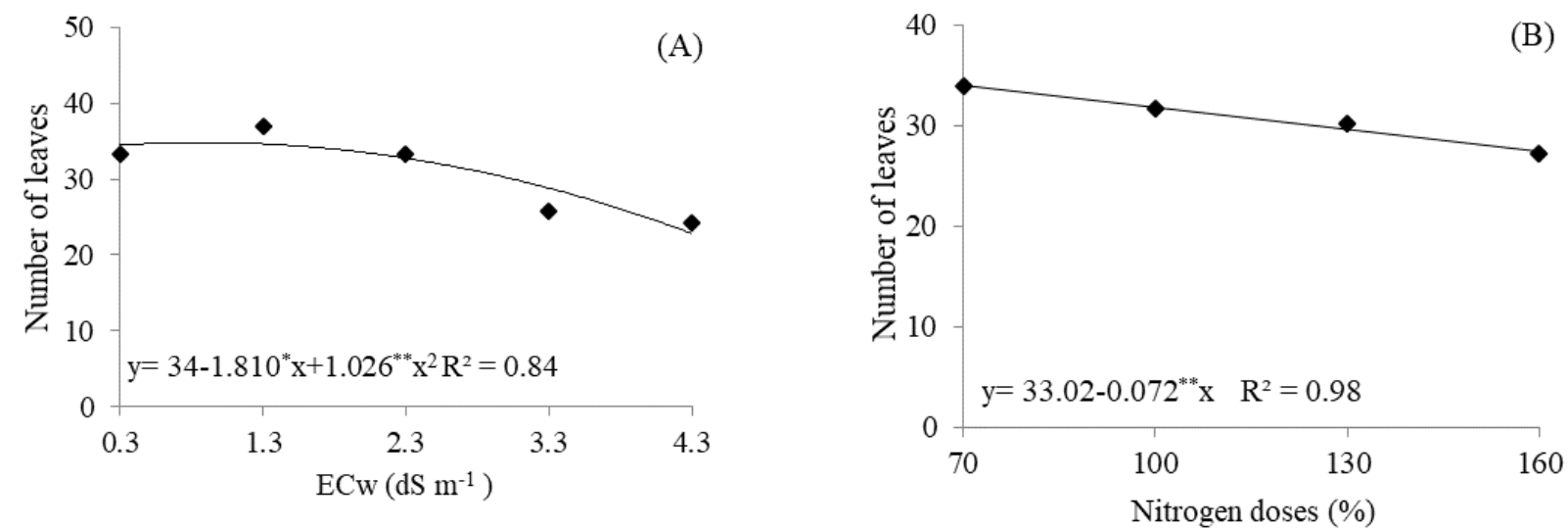

Fig 2. Number of leaves of West Indian cherry rootstock as a function of irrigation water salinity - ECW (A) and nitrogen doses (B) at 165 days after emergence.

Table 2. Summary of the analysis of variance for absolute growth rate of plant height ( $\left.A G R_{P H}\right)$ from 45 to 165 days after emergence (DAE), shoot dry phytomass (SDP), total dry phytomass (TDP) and Dickson quality index (DQI) of CMI 102 West Indian cherry rootstock at $165 \mathrm{DAE}$.

\begin{tabular}{|c|c|c|c|c|c|}
\hline \multirow{2}{*}{ Source of variation } & \multirow{2}{*}{ DF } & \multicolumn{4}{|c|}{ Mean squares } \\
\hline & & $A G R_{P H}$ & SDP & TDP & DQI \\
\hline Saline levels (SL) & 4 & $0.04^{* *}$ & $6.00^{*}$ & $28.58^{* *}$ & $0.12^{*}$ \\
\hline Linear regression & 1 & $0.13^{* *}$ & $18.62^{* *}$ & $103.70^{* *}$ & $0.36^{* *}$ \\
\hline Quadratic regression & 1 & $0.006^{\mathrm{ns}}$ & $0.008^{\mathrm{ns}}$ & $0.30^{\mathrm{ns}}$ & $0.10^{* *}$ \\
\hline $\mathrm{N}$ doses (ND) & 3 & $0.01^{\mathrm{ns}}$ & $2.18^{\mathrm{ns}}$ & $0.47^{\text {ns }}$ & $0.04^{*}$ \\
\hline Linear regression & 1 & $0.02^{*}$ & $1.18^{\mathrm{ns}}$ & $0.03^{\mathrm{ns}}$ & $0.09^{* *}$ \\
\hline Quadratic regression & 1 & $0.01^{\mathrm{ns}}$ & $4.19^{\mathrm{ns}}$ & $1.28^{\mathrm{ns}}$ & $0,02^{\text {ns }}$ \\
\hline Interaction (SL x ND) & 12 & $0.007^{\mathrm{ns}}$ & $2.46^{\mathrm{ns}}$ & $1.62^{\mathrm{ns}}$ & $0.02^{\mathrm{ns}}$ \\
\hline Blocks & 3 & $0.03^{*}$ & $1.45^{\mathrm{ns}}$ & $15.64^{* *}$ & $0.25^{\mathrm{ns}}$ \\
\hline CV (\%) & & 18.25 & 30.16 & 18.01 & 29.58 \\
\hline
\end{tabular}

$\mathrm{ns}, * *, *$ respectively not significant, significant at $\mathrm{p}<0.01$ and $\mathrm{p}<0.05$ 
Table 3. The physical and chemical characteristics of the substrate used in the experiment.

\begin{tabular}{|c|c|c|c|c|c|c|c|c|c|c|c|}
\hline \multirow{3}{*}{\multicolumn{2}{|c|}{ Textural classification }} & \multirow{3}{*}{\multicolumn{2}{|c|}{$\begin{array}{l}\text { Apparently } \\
\text { density } \\
\mathrm{kg} \mathrm{dm}^{-3}\end{array}$}} & \multirow{3}{*}{$\begin{array}{l}\text { Total porosity } \\
\%\end{array}$} & \multirow{3}{*}{\multicolumn{2}{|c|}{$\begin{array}{l}\text { Organic } \\
\text { matter } \\
\mathrm{g} \mathrm{kg}^{-1} \\
\end{array}$}} & \multirow{4}{*}{$\begin{array}{l}\mathrm{P} \\
\frac{\mathrm{mg} \mathrm{dm}^{-3}}{17}\end{array}$} & \multicolumn{4}{|c|}{ Exchange complex } \\
\hline & & & & & & & & $\mathrm{Ca}^{2+}$ & $\mathrm{Mg}^{2+}$ & $\mathrm{Na}^{+}$ & $\mathrm{K}^{+}$ \\
\hline & & & & & & & & \multicolumn{4}{|c|}{--- $\mathrm{cmol}_{\mathrm{c}} \mathrm{dm}^{-3}$} \\
\hline Sand & & 1.38 & & 47.00 & 32 & & & 5.4 & 4.1 & 2.21 & 0.28 \\
\hline \multicolumn{12}{|c|}{ Saturation extract } \\
\hline $\mathrm{pH}_{\mathrm{se}}$ & $\begin{array}{l}\mathrm{EC}_{\mathrm{se}} \\
\mathrm{dS} \mathrm{m}^{-1}\end{array}$ & $\mathrm{Ca}^{2+}$ & $\mathrm{Mg}^{2+}$ & $\mathrm{K}^{+}$ & $\mathrm{Na}^{+}$ & $\mathrm{Cl}^{-}$ & $\mathrm{SO}_{4}^{2-}$ & $\mathrm{CO}_{3}{ }^{2-}$ & $\mathrm{HCO}_{3}^{-}$ & \multicolumn{2}{|c|}{$\begin{array}{l}\text { Saturation } \\
\%\end{array}$} \\
\hline 7.41 & 1.21 & 2.50 & 3.75 & 4.74 & 3.02 & 7.50 & 3.10 & 0.00 & 5.63 & 27. & \\
\hline
\end{tabular}

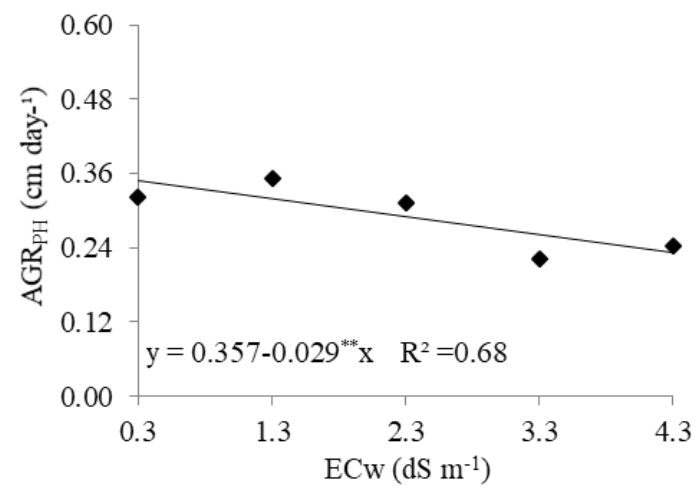

Fig 3. Absolute growth rate of plant height $\left(A G R_{P H}\right)$ of West Indian cherry rootstocks as a function of irrigation water salinity - ECW at 45-165 days after emergence.

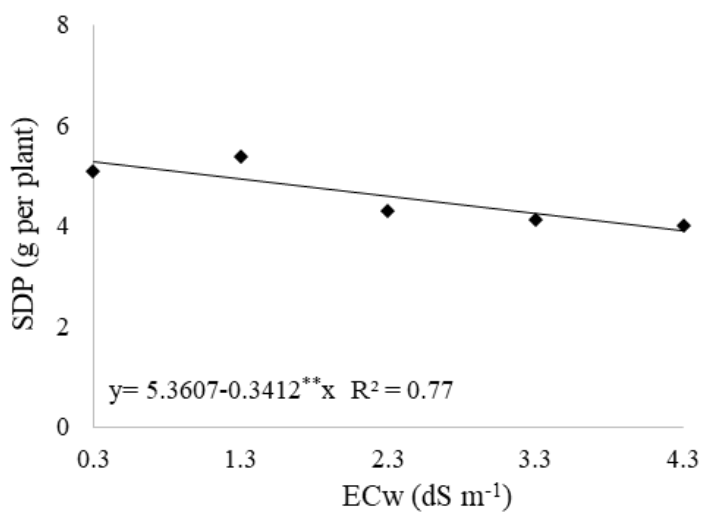

Fig 4. Shoot dry phytomass (SDP) of West Indian cherry rootstocks as a function of irrigation water salinity at 165 days after emergence.

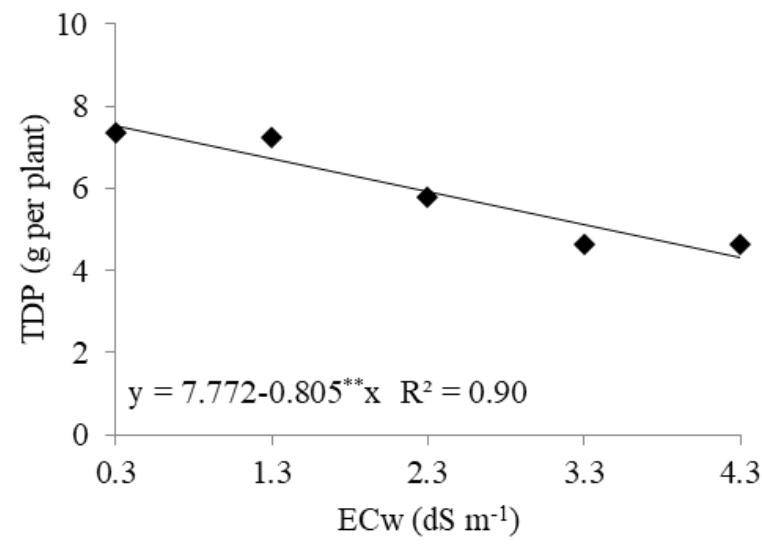

Fig 5. Total dry phytomass (TDP) of West Indian cherry rootstocks as a function of irrigation water salinity at 165 days after emergence. 

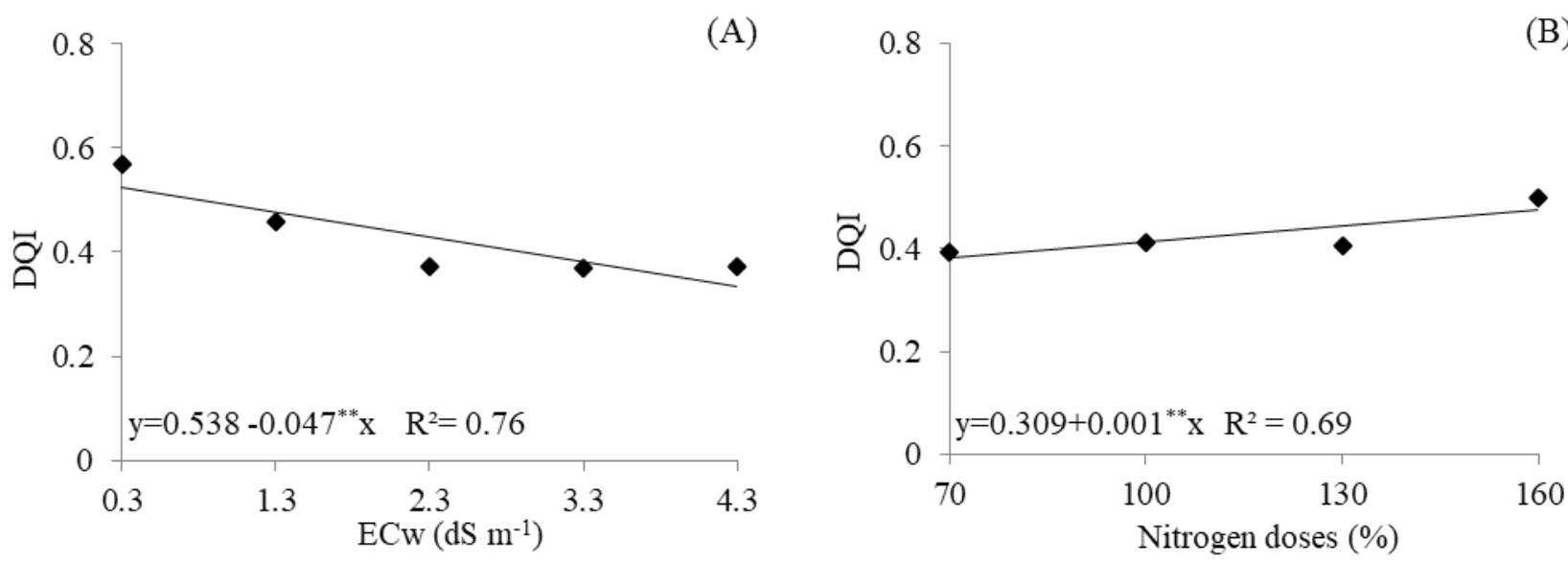

Fig 6. Dickson quality index (DQI) of West Indian cherry as a function of water salinity (A) and nitrogen doses (B) at 165 days after emergence.

Grande (UFCG), Campus of Pombal - PB, Brazil (648'16" S; 37049'15" W; 144 m).

The experiment was set up in a randomized blocks, in $5 \times 4$ factorial scheme, with four replicates and two plants per plot. Treatments consisted of different levels of irrigation water electrical conductivity - ECw (0.3-Control, 1.3, 2.3, 3.3 and $\left.4.3 \mathrm{dS} \mathrm{m}^{-1}\right)$ associated with nitrogen doses $(70,100$, 130 and $160 \%$ of $\mathrm{N}$ recommendation), and the $100 \%$ dose corresponded to $600 \mathrm{mg}$ of $\mathrm{N} \mathrm{dm}^{-3}$ (Ferreira, 2014). Solutions of different salinity levels were obtained by mixing publicsupply water $\left(\mathrm{ECW}=0.3 \mathrm{dS} \mathrm{\textrm {m } ^ { - 1 }}\right.$ ) and sodium chloride $(\mathrm{NaCl})$, calcium chloride $\left(\mathrm{CaCl}_{2} \cdot 2 \mathrm{H}_{2} \mathrm{O}\right)$ and magnesium chloride $\left(\mathrm{MgCl}_{2} \cdot 6 \mathrm{H}_{2} \mathrm{O}\right)$, in equivalent proportion of $7: 2: 1$, which is the predominant ratio in the main water sources available for irrigation in Northeast Brazil (Medeiros, 1992), following the relationship between ECW and concentration of salts $\left(\mathrm{mmol}_{\mathrm{c}}\right.$ $\mathrm{L}^{-1}=\mathrm{EC} \times 10$ ) (Rhoades et al., 1992).

\section{Plant materials}

The genetic material was CMF102 West Indian cherry. The West Indian cherry plant is a shrub (hairless), medium-sized, 2 to $3 \mathrm{~m}$ tall, dense with scattered branches, opposite leaves, short petiole, oval and elliptic-petiolate, measuring between 2.5 and $7.5 \mathrm{~cm}$. The base and especially the apex of the leaves are acute, dark green in color on the upper surface and pale green on the lower surface (Calgaro and Braga, 2012).

\section{Establishment and management of the experiment}

West Indian cherry rootstocks were produced in plastic bags with capacity for $1150 \mathrm{~mL}$, perforated at the bottom to allow free water drainage. The bags were filled using a substrate composed of Fluvic Neosol + Bovine manure + Sand $(82,3$ and $15 \%$, respectively). Five seeds were equidistantly planted at $1.5 \mathrm{~cm}$ depth. The bags were placed on metal benches, at height of $0.8 \mathrm{~m}$ from the soil

The physical and chemical characteristics of the soil in the study (Table 3) were determined according to Claessen (1997) at the Soil and Plant Laboratory of the CCTA/UFCG. During the period of germination and emergence of seedlings, the soil was maintained close to field capacity using water from the local supply system (ECW of $0.3 \mathrm{dS} \mathrm{m}^{-1}$ ).
Solutions with different salt levels began to be applied at 30 days after emergence (DAE), through daily irrigations, manually, using a graduated cylinder, according to the treatment. Irrigations were performed based on plant water requirement, determined by drainage lysimetry (twenty bags were chosen and collectors were installed) by daily application in the late afternoon with the volume to be applied. It was determined by the difference between the applied volume and the volume drained in the previous irrigation (Bernardo et al., 2006). Every 10 days, a leaching fraction of 0.15 was applied based on the volume applied in this period, to reduce salt accumulation in the substrate.

Nitrogen fertilization began 40 DAE and was split into 14 equal parts, applied every week using urea $(45 \% \mathrm{~N})$ as source of $\mathrm{N}$. The fertilizer was applied through fertigation using water with electrical conductivity of $0.3 \mathrm{dS} \mathrm{m}^{-1}$ for all treatments.

\section{Traits measured}

The growth of West Indian cherry rootstock (CMF 102) was evaluated at 165 DAE. The characteristics such as plant height $(\mathrm{PH})$, stem diameter (SD), number of leaves (NL), leaf area (LA), shoot (SDP) and total dry phytomass (TDP) and Dickson quality index (DQI) were recorded. Additionally, the absolute growth rate of plant height $\left(A G R_{P H}\right)$ was evaluated from 45 to 165 DAE.

$\mathrm{PH}$ was measured from soil surface to the apical meristem, whereas SD was measured $3 \mathrm{~cm}$ above the soil level. The NL was determined by counting the fully expanded leaf blades. LA was determined as recommended by Medeiros et al. (2010), using Eq. 1:

$\mathrm{LA}=0.7097 \times \mathrm{L} \times \mathrm{W}$.

Where; $L A=$ leaf area $\left(\mathrm{cm}^{2}\right), L=$ leaf length and $W=$ leaf width.

The absolute growth rate (AGR) was determined using the methodology proposed by Benincasa (2003), as described in Eq. 2:

$\operatorname{AGR}=\frac{\left(A_{2}-A_{1}\right)}{\left(t_{2}-t_{1}\right)}$

Where; $A G R_{\mathrm{PH}}=$ absolute growth rate, $\mathrm{A}_{2}=$ plant growth at time $t_{2}, A_{1}=$ plant growth at time $t_{1}$, and $t_{2}-t_{1}=$ time difference between measurements. 
To determine dry phytomass accumulation, the stem of each plant was cut close to the soil and the aboveground material was separated into different parts (stem and leaves). The material was dried in a forced-air oven at 65 o $C$ until constant weight to determine shoot (SDP) and total dry phytomass (TDP), based on the sum of leaves and stem.

Rootstock quality was determined by the Dickson quality index (DQI) for seedlings, using the formula of Dickson et al. (1960), described by Eq. 3.

$\mathrm{DQI}=\frac{(\mathrm{TDP})}{(\mathrm{PH} / \mathrm{SD})+(\mathrm{SDP} / \mathrm{RDP})}$

Where; $\mathrm{DQI}=$ Dickson quality index, $\mathrm{PH}=$ plant height $(\mathrm{cm})$, $\mathrm{SD}=$ stem diameter $(\mathrm{mm}), \mathrm{TDP}=$ total dry phytomass $(\mathrm{g})$, $\mathrm{SDP}=$ shoot dry phytomass $(\mathrm{g})$ and $\mathrm{RDP}=$ root dry phytomass (g).

\section{Statistical analysis}

The data were subjected to analysis of variance by F-test at 0.05 and 0.01 probability levels. In cases of significance, linear and quadratic polynomial regressions were applied using the statistical program SISVAR (Ferreira, 2011). The choice of regression was made by better adjustment on the basis of coefficient of determination $\left(R^{2}\right)$ and taking into account a probable biological explanation (Lima et al, 2014).

\section{Conclusion}

Irrigation with $\mathrm{ECW}$ up to $2.22 \mathrm{dS} \mathrm{m}^{-1}$ led to a maximum reduction of $10 \%$ in growth and in the quality of CMF 102 rootstock. Highest growth of CMF 102 West Indian cherry rootstock was obtained with fertilization equivalent to $70 \%$ of recommended $\mathrm{N}$ dose. The plants of West Indian cherry irrigated with water of $4.3 \mathrm{dS} \mathrm{m}^{-1}$ presented acceptable Dickson quality index; therefore, seedlings with IQD higher than 0.2 are considered of good quality. In general, West Indian cherry plants can be classified as sensitive to the irrigation water salinities higher than $0.3 \mathrm{dS} \mathrm{m}^{-1}$. No significant effect was found for the interaction between water salinity and $\mathrm{N}$ doses.

\section{Acknowledgements}

To the Coordination for the Improvement of Higher Education Personnel - CAPES, for granting the scholarship and to the National Institute of Science and Technology in Salinity - INCTSal, for funding the project.

\section{References}

Almeida GF, Aguiar CML. Silva M, Santos RM (2014) Floração e frutificação da aceloreira (Malphigia emarginata DC.) em uma área no Semiárido Brasileiro. Magistra. 28:1- 2.

Alves AN, Gheyi HR, Uyeda CA, Soares FAL, Nobre RG, Cardoso JAF (2012) Uso de águas salinas e adubação nitrogenada no cultivo da mamoneira BRS-energia. Rev Bras Agric Irrigada. v.6, n.2, p. 151-163.

Amorim DA de, Souza HA de, Rozane DE, Montes RM, Natale W (2015) Adubação nitrogenada e potássica em goiabeiras 'Paluma': II. Efeito no estado nutricional das plantas. Rev Bras Frutic. 37:210-219.

Benincasa MMP (2003) Análise de crescimento de plantas, noções básicas. 2.ed. Jaboticabal: FUNEP. 41p.
Bernardo S, Soares AA, Mantovani EC (2006) Manual de irrigação. 8.ed., Viçosa: UFV, 625 p.

Calgaro M, Braga MB (Ed.) (2012) A cultura da acerola. 3ed. revisada e ampliada. - Brasília, DF: Embrapa. 144p. (Coleção plantar, 69).

Claessen MEC (Org.) (1997) Manual de métodos de análise de solo. 2.ed. rev. atual. Rio de Janeiro: Embrapa-CNPS, p.212. (Embrapa-CNPS. Documentos, 1).

Dickson A, Leaf AL, Hosner JF (1960) Quality appraisal of white spruce and white pine seedling stock in nurseries. Forest Chron. 36:10-13.

Ferreira DF (2011) Sisvar: A computer statistical analysis system. Ciênc Agrotec.35:1039-1042.

Ferreira EP, Brito LTL, Nascimento T, Rolim Neto FC, Cavalcante NB (2016) Uso eficiente da água de chuva armazenada em cisterna para produção de hortaliças no Semiárido pernambucano. Rev Verde de Agroec e Desenv Sust. 11:01-07.

Ferreira KS (2014) Crescimento e acúmulo de nutrientes em mudas de aceroleira adubadas com nitrogênio e potássio. (Dissertação de Mestrado). Universidade Federal de São João Del Rei. $50 \mathrm{f}$.

Furtado G de F, Sousa Junior JR de, Xavier DA, Andrade EM. G, Sousa JRM de (2014) Pigmentos fotossintéticos e produção de feijão Vigna ungüiculada L. walp sob salinidade e adubação nitrogenada. Rev Verde de Agroec e Desenv Sust. 9:291-299.

Gomes KR, Amorim AV, Ferreira FJ, Filho, FL Lacerda, CF, Gomes-Filho E (2011) Respostas de crescimento e fisiologia do milho submetido a estresse salino com diferentes espaçamentos de cultivo. Rev Bras Eng Agríc Ambient.15: 365-370.

Leal RM, Natale W, Prado R de M, Zaccaro RP (2007) Adubação nitrogenada na implantação e na formação de pomares de caramboleira. Pesq Agropec Bras. 42:11111119.

Lima GS de, Nobre RG, Gheyi HR, Soares LA dos A, Silva AO da. (2014) Crescimento e componentes de produção da mamoneira sob estresse salino e adubação nitrogenada. Eng Agríc. 34:854-866.

Lima GS, Nobre RG, Gheyi HR, Soares LAA, Silva AO (2015) Produção da mamoneira cultivada com águas salinas e doses de nitrogênio. Rev Ciênc Agron. 46:1-10.

Lima LA, Oliveira F de A, Alves R de C, Linhares PSF, Medeiros AMA de, Bezerra FMS. (2015) Tolerância da berinjela à salinidade da água de irrigação. Rev Agroambiente, 9:2734.

Maia VM, Salomão LCC, Cantarutti RB, Venegas VHA, Couto FAA (2003) Efeitos de dose de nitrogênio, fósforo e potássio sobre os componentes da produção e a qualidade de bananas 'Prata Anã' no distrito agroindustrial de Jaíba. Rev Bras Frutic. 25:319-322.

Medeiros JF de (1992) Qualidade de água de irrigação e evolução da salinidade nas propriedades assistidas pelo GAT nos Estados de RN, PB e CE. (Dissertação de Mestrado). Universidade Federal da Paraíba, Campina Grande. 173p.

Medeiros LS, Tenório AT, Santos PR, Costa KDS, Paes RA, Madalena JAS (2010) Estimativa da área foliar da acerola (Malphigia glabra L.) utilizando dimensões lineares. In: 62응 Reunião Anual da SBPC, Natal-RN.

Nascimento IB, Medeiros JF, Alves SSV, Lima BL C, Silva JLA (2015) Desenvolvimento inicial da cultura do pimentão 
influenciado pela salinidade da água de irrigação em dois tipos de solos. Agropec Cient Semi-Árido. 11:37-43.

Nobre RG, Gheyi HR, Correia KG, Soares FAL, Andrade LO de (2010) Crescimento e floração do girassol sob estresse salino e adubação nitrogenada. Rev Ciênc Agron. 41:358365.

Nunes JC, Cavalcante LF, Lima Neto AJ, Rebequi AM, Diniz BLMT, Gheyi HR (2012) Comportamento de mudas de nim à salinidade da água em solo não salino com biofertilizante. Rev Bras Eng Agríc Ambient.16:1152-1158.

Oliveira FA, Carrilho MJSO, Medeiros JF, Maracajá PB, Oliveira MKT (2011) Desempenho de cultivares de alface submetidas a diferentes níveis de salinidade da água de irrigação. Rev Bras Eng Agríc Ambient. 15:771-777.

Oliveira FA de, Medeiros de JF, Oliveira de MKT, Souza AAT, Ferreira JÁ, Souza MS (2013) Interação entre salinidade e bioestimulante na cultura do feijão caupi. Rev Bras Eng Agríc Ambient. 17:465-471.

Oliveira FDA, Guedes RA, Gomes LP, Bezerra FM, Lima LA, Oliveira MK (2015) Interação entre salinidade e bioestimulante no crescimento inicial de pinhão-manso. Rev Bras Eng Agríc Ambient.19:204-210.

Rhoades JD, Kandiah AM, Marshali AM (2000) Uso de águas salinas para produção agrícola. Campina Grande: UFPB, 117p. Estudos da FAO, Irrigação e drenagem, 48, 205 revisado.

Silva EM, Nobre RG, Souza LP, Pinheiro FWA, Andrade ABA (2015) Efeito da adubação nitrogenada na formação de mudas de goiabeira irrigadas com águas salinas. Rev Verde Agroec Desenv Sust.10:42-48.
Sousa ABO, Bezerra MA, Farias FC (2011) Germinação e desenvolvimento inicial de clones de cajueiro comum sob irrigação com água salina. Rev Bras Eng Agríc Ambient. 15:390-394.

Souza F de F, Deon MDI, Castro JM da C, Lima MAC de, Rybka ACP, Freitas ST de (2013) Principais variedades de aceroleiras cultivadas no submédio do Vale do São Francisco. Documento online, n. 255.

Souza L de P, Nobre RG, Silva EM da, Lima GS de, Pinheiro FWA, Almeida L L de S (2016) Formation of 'Crioula' guava rootstock under saline water irrigation and nitrogen doses. Rev Bras Eng Agríc Ambient. 20:739-745.

Souza L de P, Nobre, RG, Silva EM, Gheyi HR, Soares LA dos A (2017) Production of guava rootstock grown with water of different salinities and doses of nitrogen. Rev Ciênc Agron. 48:596-604.

Souza LP, Nobre RG, Silva EM, Pinheiro FWA, Almeida LLS (2015) Crescimento de porta-enxerto de goiabeira sob águas salinizadas e doses de nitrogênio. Rev Verde Agroec Desenv Sust. 10:53-60.

Torres EC M de, Freire JLO de, Oliveira JL de, Bandeira LB, Melo DA de, Silva AL da (2014) Biometria de mudas de cajueiro anão irrigadas com águas salinas e uso de atenuadores do estresse salino. Nativa. 2:71-78.

Travassos KD, Gheyi HR, Soares FAL, Barros HMM, Silva, N Dias, Uyeda CA, Silva FV (2012) Crescimento e desenvolvimento de variedades de girassol irrigado com água salina. Irriga. Edição especial:324-339. 